Licmoo

MOUNTAIN ENVIRONMENTAL MANAGEMENT

Discussion Paper Series

\title{
REMOTE SENSING AND RESOURCE MANAGEMENT IN THE HIMALAYAS
}

J. M. Fox

MEM Series No. 6

1991

International Centre for Integrated Mountain Development 
The opinions expressed in this publication are those of the author(s) and do not necessarily reflect the views of the International Centre for Integrated Mountain Development.

The designations employed and the presentation of the material in this publication do not imply the expression of any opinion whatsoever, on the part of the International Centre for Integrated Mountain Development, concerning the legal status of any country, territory, city, or area of its authorities; or concerning the delimitation of its frontiers and boundaries. 


\section{REMOTE SENSING AND RESOURCE MANAGEMENT IN THE HIMALAYAS}

MEM Series No. 6

J. M. Fox is a Research Associate of the Environment and Policy.Institute, East-West Centre, Honolulu, Hawaii.

International Centre for Integrated Mountain Development (ICIMOD)

Kathmandu, Nepal 
Management of natural resources and the modern technological options, available for planning and management, have been areas of primary concern for the Mountain Environmental Management Programme of ICIMOD. One of the major activities of this programme was the joint organisation of the "International Symposium on Mountain Environmental Managemnet in the

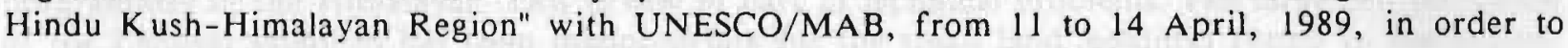
provide an opportunity for a fuller and meaningful discussion on these issues.

This was one of the papers prepared for, and presented at, this Symposium. This paper argues that the major factor limiting the efficient use of remote sensing is the lack of proper government policies for guiding resource management agencies in collecting and using this information. In addition, the paper offers a number of modest proposals for increasing the effectiveness of this technology. 


\begin{abstract}
Remote sensing offers a number of benefits for resource management problems in the Himalayas. Aerial photographs are useful for their spatial resolution and their stereoscopic capabilities. Satellite images are useful for their synoptic view of broad areas, up-to-date repetitive coverage, and reasonable prices. At present, however, few benefits are realized from remote-sensing programmes in the Himalayas. This is due in part to technical problems. The large cell resolution of the Landsat satellites has been inappropriate for the small land holdings found in the region. Researchers have not developed models for applications in mountainous terrain. And most seriously, technicians have failed to develop methods for dealing with the effects of steep terrain on satellite data.

But, more fundamentally, the failure of Himalayan nations to use remote sensing effectively is due to institutional and policy constraints. These factors include restricted access to data, remotesensing programmes run as personal fiefdoms, integragency competition, rigid bureaucracies, turf conflicts, inflexible data requirements, scarce resources, and lack of training. The most critical factor constraining the effective use of remotely-sensed information has been the failure of governments to develop policies for coordinating the collection and use of resource information on a national scale.
\end{abstract}

There are a number of useful roles a centre such as ICIMOD could play to help Himalayan nations overcome these problems. These include supporting regional meetings where scientists can share their experiences, encouraging the development of software and ecological models for use in mountainous terrain, conducting case studies in conjunction with national remote-sensing programmes, and sponsoring seminars to promote dialogue between users and collectors of remotely-sensed data. But perhaps the most significant role such centres can play is to work with government agencies to design policies for managing resource information in a coordinated manner. 


\section{CONTENTS}

\section{PREFACE}

ABSTRACT

Page

1. INTRODUCTION

2. REMOTE SENSING AND ITS BENEFITS 2

What Is Remote Sensing ?

How Does Remote Sensing Work?

What Are Some Major Remote Sensing Systems ? 5

How Are Remote-Sensing Data Analyzed? 6

What Are the Benefits of Remote Sensing ?

3. APPLICATIONS FOR RESOURCE MANAGEMENT:

EXAMPLES FROM THE HIMALAYAS

$\begin{array}{ll}\text { Applications } & 8\end{array}$

Socioeconomic Aspects of the Environment 8

Geology, Geomorphology, and Hydrology 9

Vegetation. Crops, and Soils

Land Use and Land Cover Mapping

Geographic Information Systems

Summary 14

4. INSTITUTIONALIZING THE USE OF REMOTELY-SENSED DATA

The Role of a Remote-sensing Programme 15

Limiting Factors 16 
Restricted Access to Data 16

Personal Fiefdoms

Integragency Competition $\quad 17$

Rigid Bureaucracies

Turf Conflicts $\quad 17$

Inflexible Data Requirements 18

Scarce Resources $\quad 18$

$\begin{array}{lr}\text { Training } & 18\end{array}$

Integration of Resource Information 18

Regional Remote-sensing Programmes

$\begin{array}{ll}\text { Summary } & 20\end{array}$

5. CONCLUSIONS, THE FUTURE, AND SUGGESTIONS

$\begin{array}{ll}\text { Conclusions } & 21\end{array}$

$\begin{array}{ll}\text { The Future } & 21\end{array}$

A Role for ICIMOD

ANNEX: REMOTE-SENSING PROGRAMMES

IN THE HIMALAYAN REGION

Regional Programmes $\quad 23$

Asian Institute of Technology 23

Regional Remote-sensing Programme, ESCAP 23

National Programmes 26

Bangladesh $\quad 26$

China 26

India $\quad 26$

Nepal $\quad 27$

Pakistan 27

Thailand 28

REFERENCES 